\title{
The Effect of Work Discipline on Employees Performance with Motivation as a Moderating Variables in the Inspectorate Office of Musi Rawas District
}

\author{
Surajiyo $^{1)}$, Suwarno ${ }^{2)}$, Indrawati Mara Kesuma ${ }^{3)}$, Tri Gustiherawati ${ }^{4)}$ \\ 1), 2),3),4) Universitas Bina Insan, Lubuklinggau, Indonesia
}

Email: surajiyo@univbinainsan.ac.id ${ }^{I)}$,suwarno221273@gmail.com²),fairuz.ukail@gmail.com ${ }^{3)}$, trigustiherawati@gmail.com ${ }^{4}$

\begin{abstract}
This study aims to determine the effect of work discipline and employee performance and the influence of motivation on the relationship between work discipline and employee performance. Work discipline is an attitude that is indispensable for everyone to improve performance in order to achieve organizational goals. Motivation leads to discipline, high motivation for work discipline can affect employee performance. This study uses simple regression analysis and interaction test or Moderated Regression Analysis (MRA) The population in this study includes employees at the Inspectorate Office of Musi Rawas Regency. The sample of this study amounted to 68 employees, selected using a saturated sampling method. The data collection technique used a questionnaire. The results of this study indicate that work discipline has a significant influence on employee performance (Y), as evidenced by the value for the work discipline variable () is greater than the value. This indicates a significant influence between Work Discipline () on Employee Performance (Y) at the Inspectorate Office of Musi Rawas Regency. So it can be said that the hypothesis is accepted. The next result is that the motivation variable is a moderating moderating variable in the relationship between work discipline and employee performance. Motivation as a moderation variable has an effect on the relationship between Work Discipline () and Employee Performance (Y). So, Motivation (as a Moderation variable has an effect on the relationship between Work Discipline () and Employee Performance (Y) at the Inspectorate Office of Musi Rawas Regency. Thus, it can be concluded that the hypothesis is accepted. So it can be said that the Motivation variable (as a Moderation variable affects the relationship between Work Discipline variables) () on Employee Performance (Y). Motivation as a Moderation variable has an influence on the relationship of Work Discipline and Employee Performance. Thus, giving motivation to employees is important so that motivation should be further improved at the Inspectorate Office of Musi Rawas Regency so that Employee Performance can increase even more.
\end{abstract}

Keywords: Work Discipline, Employee Performance, Motivation

\section{Introductions}

Human Resources is a factor very important and cannot even be separated from an organization, both institutions and companies. In addition, Human Resources can influence organizational development. Basically, Human Resources are people who work in an organization who act as motivator, processing and planning to achieve the goals of the organization. Human Resources must be trained and their abilities developed. Good human resource management is a major factor so that organizational goals can be achieved. Employee performance can be used as a tool to measure the quality of Human Resources. Employee work results are the results of work in quality and quantity achieved by an employee in carrying out the assigned duties and responsibilities. 
According to Mangkunegara states (2015: 67) Performance is the result of work in quality and quantity obtained by an employee in carrying out his duties in accordance with the responsibilities given to him [1].

Work discipline is a condition that affects or encourages employees to act and carry out activities in accordance with determined norms or rules.

According to Sutrisno (2015: 89) work discipline is a person's attitude in accordance with existing regulations and work procedures. Employee work discipline is a training that tries to improve and shape employee knowledge, attitudes and behavior so that employees can work better.

Motivation is also important in improving employee performance. Motivation is taken from the Latin word "movere" which means: encouragement or driving force. According to Wibowo (2016: 322) motivation is an impetus for a series of human behavior processes in achieving goals [3]. Motivation is something that influences someone to do activities. In other words, motivation can be said to drive one's behavior. Motivation leads to discipline, high motivation for work discipline can affect employee performance. Thus, motivation can lead to a disciplined attitude that can affect employee performance.

Moderator or moderating variables are variables that can have an influence on the relationship between the independent and dependent variables. According to Sugiyono (2017: 39) This variable is called the second independent variable. The moderation variable is the relationship between the independent variable (free) and the dependent variable (bound) [4].

The Inspectorate Office of Musi Rawas Regency is a Government Agency that is tasked with assisting the Regent to guide and supervise the implementation of government affairs which fall under regional authority and assistance tasks by regional apparatus based on the principles of autonomy and assistance assigned to the district. Therefore, employees are required to comply with all regulations in the inspectorate office and can work in a disciplined manner so that tasks in the Inspectorate Office can be accomplished.

Based on the results of observations and research interviews related to real conditions at the Inspectorate Office of Musi Rawas Regency, there are still employees who have not reached performance standards in carrying out their duties. In terms of discipline there are several problems, namely there are still employees who have not carried out their duties properly, there is still a lack of self-awareness in terms of attendance and work completion, there are still employees who arrive late, there are still employees who come home from work not on time. Then the problem of motivation is the lack of motivation given by the leadership in the form of encouragement so that employees are less motivated, there is still a lack of information provided about organizational goals and remuneration for work results. Meanwhile, the employee's performance has not been optimal in accordance with organizational goals, it is still not suitable in completing the tasks that are their responsibility and the level of timeliness of employees in completing tasks is still not optimal.

The problems discussed are as follows:

1. Does Work Discipline affect Employee Performance in the Inspectorate Office of Musi Rawas Regency;

2. Does motivation as a moderating variable affect the relationship between work discipline and employee performance at the Inspectorate Office of Musi Rawas Regency. 
The research objectives in this study include:

1. To determine the effect of work discipline on employee performance at the Inspectorate Office of Musi Rawas Regency;

2. To determine the effect of motivation as a moderating variable on the relationship of work discipline and employee performance at the Inspectorate Office of Musi Rawas Regency.

\section{Literature Review}

\subsection{Employee Performance}

Performance is a manifestation of ability in the form of real work. Performance is the work achieved by employees in carrying out tasks and jobs that come from the organization.

According to Sumardjo (2018: 193) performance in English is called job performance or actual performance or level of performance, which is the level of success of employees in completing their work [5].

Meanwhile, according to Wibowo (2016: 3) performance is the implementation of plans that have been prepared by human resources who have the ability, competence, motivation, and interests [3]

Based on some of the opinions of the experts above, it can be concluded that performance is about doing the job and the results achieved from that work.

\subsection{Work Discipline}

Work discipline is a condition that causes or encourages employees to act and carry out all activities in accordance with predetermined norms or rules.

Hasibuan states (2018: 193) that discipline is the awareness and willingness of a person to obey all company regulations and applicable social norms [6].

According to Siagian (2016: 305) employee discipline is a form of training that seeks to improve and shape knowledge, attitudes and behaviors that make employees try to work cooperatively with other employees and improve performance [7].

According to Sutrisno (2015: 86) work discipline shows a condition or attitude of respect that exists in employees towards company rules or regulations [2].

Based on some according to the experts above, it can be concluded that work discipline shows a condition or attitude of respect that exists in each individual for the rules and regulations. Basically, work discipline is the attitude and behavior of employees' obedience or obedience to the applicable written and unwritten regulations.

\subsection{Motivation}

Motivation comes from the Latin word "movere" which means encouragement or driving force. Motivation is given to humans, especially to subordinates or followers. This motivation is important because it is expected by each individual employees are willing to work hard and are enthusiastic to achieve high performance.

According to Handoko in Prihantoro (2015: 11) motivation is a state in a person that encourages the individual's desire to carry out certain activities to achieve goals [8]. 
According to Sutrisno (2015: 109) motivation is a factor that encourages a person to do a certain activity, therefore motivation is often interpreted as a driving factor for one's behavior [2].

According to Baron in Wibowo stated (2016: 322) motivation is a series of processes that arouse, direct and maintain human behavior towards achieving goals [3]

Based on several opinions according to the experts above, it can be concluded that motivation is the impetus for a series of human behavior processes in achieving goals.

\subsection{Framework of thinking}

The framework of thinking in this study are:

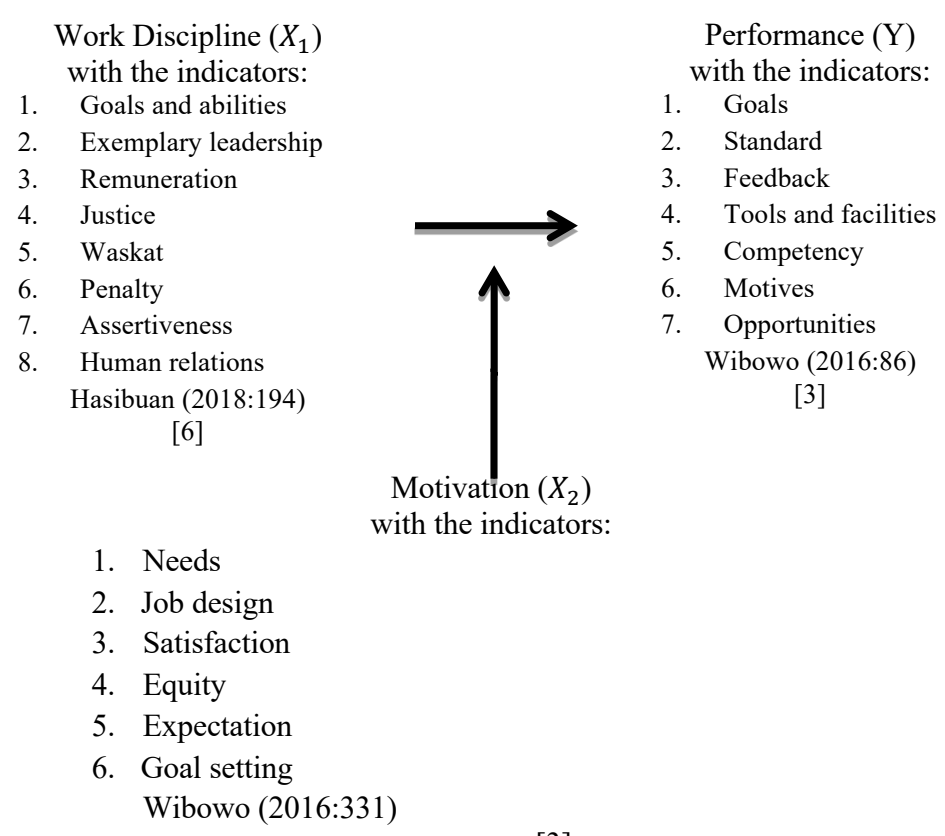

Figure 2.1 Framework Think

\subsection{Hypothesis}

According to Sugyiono (2017: 63) the hypothesis is a temporary answer to the formulation of research problems, where the formulation of the research problem has been stated in the form of a question sentence [4].

The hypotheses in this study include:

a. It is suspected that there is an influence of discipline on the performance of employees at the Inspectorate of Musi Rawas Regency.

b. It is suspected that motivation as a moderating variable affects the relationship of work discipline and work performance of employees at the Inspectorate of Musi Rawas Regency.

\section{Research Methodology}

\subsection{Place and time of research}

a. Place of research 
This research was conducted at the Inspectorate office of Musi Rawas Regency which is located at Jl. Sulaiman Amin Musi Rawas Muara Beliti Regency Office Complex, South Sumatra Province Postal Code 31661 Phone / Fax: (0733) 4540094.

\section{b. Research time}

The time of this research was carried out for 6 months, starting from January to June 2020.

\subsection{Research design}

This study discusses the effect of work discipline on employee performance with motivation as a moderating variable in the Inspectorate of Musi Rawas Regency. The nature of this research is quantitative research methods. According to Winarni (2018:24) quantitative research can be defined as a research method based on a positive philosophy that is used to research on certain populations or samples [12].

Meanwhile, according to Sugiyono (2017: 7) quantitative research is called a traditional method, this method is called a positivistic method because it is based on a positive philosophy. This method is called a quantitative method because the research data is in the form of numbers and the analysis uses statistics [4]

\subsection{Research Variables and Variable Operational Definitions}

a. Research variable

According to Sugiyono (2017: 39) various variables in research:

1) Independent Variable: this variable is often referred to as the stimulus, predictor, and antecedent variable. In Indonesian it is called the independent variable. The independent variable is the variable that affects or causes the change or the emergence of the dependent variable (dependent).

2) Dependent Variable: often referred to as the output variable, criterion, consequent. In Indonesian it is called the dependent variable. The dependent variable is the variable that is influenced or becomes the result of the independent variable.

3) Moderator / Moderation variables: are variables that influence (strengthen and weaken) the relationship between independent and dependent variables. The variable is also called the second independent variable [4].

The research variables that are the variables in this study are:

1) The variable is work discipline as an independent or independent variable.

2) The variable is motivation as a moderating variable.

3) The variable $Y$ is performance as the dependent or dependent variable.

\subsection{Population and Sample}

In this study, the total population of all employees of the Inspectorate of Musi Rawas Regency was 68 people consisting of 7 employees with high school graduates, 47 employees with undergraduate degrees and 12 employees with S2 graduates, 2 employees with D3 graduates. In this study using saturated sampling technique. According to Sugiyono (2017: 82) Saturated sampling is a sampling technique when all members of all populations are used as samples [4]. In the population study, all employees of the Inspectorate of Musi Rawas Regency were 68 people, so the sample size of this study was 68 people. 


\subsection{Research Instruments}

The research instrument used in this research is a questionnaire or questionnaire using a Likert scale, according to Sugiyono (2017: 93) the Likert scale is used as a tool to measure the attitudes, opinions and perceptions of a person or group of people about social phenomena [4]. In research, this social phenomenon has been specifically determined by researchers, which is referred to as research variables.

The answer to each instrument item that uses the Likert scale has a gradient from very positive to very negative, for the purposes of quantitative analysis, the answer can be given the following score:

a. Strongly agree given a score of 5

b. Agree given a score of 4

c. Hesitant was given a score of 3

d. Disagree is given a score of 2

e. Strongly disagree given a score of 1

\subsection{Validity test}

According to Winarni (2018: 175) validity is the degree of accuracy between the data that occurs in the object of research and the data reported by researchers [12], while according to Sugiyono (2017: 121) valid means that the instrument can be used to measure what should be measured [4] ].

The validity test is written and calculated by SPSS using the product moment correlation technique.

\subsection{Reliability Test}

According to Winarni (2018: 176) reliability is related to the degree of consistency and stability of data or findings [12]. A questionnaire is called reliable or reliable if someone's answer to a question is consistent or stable over time. The reliability test that will be used in this study is to use SPSS, namely the Cronbach Alpha statistical test.

\subsection{Classic assumption test}

\subsubsection{Normality test}

The normality test is a test carried out with the aim of assessing the distribution of data in a group of data or variables, whether the data distribution is normally distributed or not to see normally distributed data or cannot use chi squared () written and calculated by SPSS Criteria:

-Chi squared count $>$ chi squared table, the data is not normally distributed

-Chi squared count $<$ chi squared table, the data is normally distributed

Sugiyono (2017: 174) [4]

\subsubsection{Linearity Test}

Linearity test aims to determine whether two variables have a significant linear relationship or not. To see the effect of work discipline on employee performance with motivation as a moderating variable. The linearity test is written and calculated by SPSS using a simple linear regression analysis mathematical equation which is written as follows: 


$$
Y^{\prime}=a+b X
$$

Information :

Y ': The predicted value

a: Constants

b: regression coefficient

$\mathrm{X}$ : The value of the independent variable

Sugiyono (2017: 188) [4]

\subsection{Data analysis technique}

\subsubsection{Simple Linear Regression}

Simple linear regression aims to examine the influence of work discipline or motivation (independent) on employee performance as the dependent variable.

\subsubsection{Correlation coefficient}

Testing the contribution of the influence of the independent variable $(\mathrm{X})$ on the dependent variable (Y), can be seen from the correlation coefficient where (). This shows that if it is closer to -1 , the effect of the independent variable $(\mathrm{X})$ on the dependent variable $(\mathrm{Y})$ is getting stronger. Conversely, if it is closer to 0 , the effect of the independent variable (X) on the dependent variable $(\mathrm{Y})$ is getting weaker.

\subsubsection{T test}

The $t$ test aims to determine whether the independent variable or the independent variable (X) partially (individually) affects the active variable or the dependent variable (Y).

\subsubsection{Moderation Test}

To see the effect of work discipline on employee performance with motivation as a moderating variable. The moderation test is written and calculated by SPSS using the mathematical equation interaction test or Moderated Regression Analysis (MRA) written as follows:

\section{Research Result}

\subsection{Validity and Reliability Test}

\subsubsection{Validity test}

\section{a. Work Discipline Validity Test Results ()}

The validity test of Work Discipline () was carried out on 15 respondents at the Inspectorate Office of Lubuklinggau City with 24 statements, $=0.05, \mathrm{n}=15$ was 0.514 . In other words, all statement items regarding the Work Discipline variable () are declared valid, because overall $(\mathrm{CITC})>$ is at a significant level of $5 \%$ so that for the whole it is feasible to do further research.

\section{b. Motivation Validity Test Results ()}

The validity test of Motivation () was conducted on 15 respondents at the Inspectorate Office of Lubuklinggau City with 18 statements, $=0.05, \mathrm{n}=15$ was 0.514 . In other words, all statement items regarding the Motivation variable () are declared valid, because overall (CITC) is $>$ at a significant level of $5 \%$ so that for the whole it is feasible to do further research. 


\section{c. Employee Performance Validity Test Results (Y)}

The performance validity test $(\mathrm{Y})$ was carried out on 15 respondents at the Inspectorate Office of Lubuklinggau City with 21 statements, $=0.05, \mathrm{n}=15$ was 0.514 . In other words, all statement items regarding the Employee Performance variable (Y) are declared valid, because overall (CITC) $>$ is at a significant level of $5 \%$ so that for the whole it is feasible to do further research.

\subsection{Reliability Test}

\subsubsection{Reliability Test Analysis Results}

The correlation between the work discipline variable score (), Cronbach's Alpha value is 0.956 . Motivation variable (), Cronbach's Alpha value is 0.967 . While the performance variable (Y), Cronbach's Alpha value is 0.945 . With this, $\mathrm{n}=15$ for the significance level $=5 \%$ is 0.514 . It means that of all variables the Alpha value is $>0.514$. So the questionnaire as a measuring tool in this study has met the reliability requirements, so that it can be used as a measuring tool for further analysis.

\subsection{Classic assumption test}

\section{a. Normality test}

The normality test is a form of test that is carried out to assess the distribution of data in a group of data or variables.

The calculated Chi-Square value for the work discipline variable is 31,000 . The Chi-Square value calculated for the motivation variable is 59,000. The Ci-Square value calculated for the work performance variable is 61,706 . With the Chi-Square table value $\mathrm{dk}$ (degrees of freedom) $68-1=67$ for the significance level $=0.05$ is 87.1081 . It means, from all Chi-Square values $<$ table Chi-Square values, the distribution of all variables is normal. [4]

\section{b. Normality test}

The normality test is a form of test that is carried out to assess the distribution of data in a group of data or variables.

The calculated Chi-Square value for the work discipline variable is 31,000. The Chi-Square value calculated for the motivation variable is 59,000. The Ci-Square value calculated for the work performance variable is 61,706 . With the Chi-Square table value $\mathrm{dk}$ (degrees of freedom) $68-1=67$ for the significance level $=0.05$ is 87.1081 . It means, from all Chi-Square values $<$ table Chi-Square values, then the distribution of all variables is normal. (Sugiyono, 2017: 174) [4]

\section{c. Linearity Test}

Test the Linearity of Work Discipline on Employee Performance

Linearity test aims to determine whether two variables have a significant linear relationship or not. Tests on SPSS 23 using the ForLinearity Test with a significance level of 0.05 . If the deviation from linearity value is greater than 0.05 , it can be stated that the model is linear. From the table above, the sig value is $0.138>0.05$, thus it is stated that the Work Discipline variable () is linear. (Sugiyono, 2017: 188)

\section{Hypothesis Test Results}

a. Analysis of Work Discipline Variables (X1) on Employee Performance (Y) 


\section{Simple Linear Regression}

From the results of the regression test that the author conducted on the Work Discipline variable () on Employee Performance (Y). It can be seen that the Employee Performance variable (Constant) has a significant value of $0,000(\mathrm{Sig}=0,000<=0.05)$ and also the Work Discipline variable () has a significant value of $0,000(\mathrm{Sig}=0,000<=0.05)$. This illustrates that the results of this study are significant. This also illustrates that there is a significant influence between the work discipline variable () on employee performance $(\mathrm{Y})$.

\section{Constant Value}

The regression equation illustrates that the constant value of (a) is 42.080 , this means that the increase in the Work Discipline variable on the Employee Performance variable is 42.080. While the regression coefficient (b) is 0.483 , which means that every time there is an increase in one variable of work discipline. Then increase the Employee Performance variable by 0.483 units.

\section{a. Analysis of Work Discipline Variables () on Employee Performance (Y) with Motivation () as Moderation Variables}

\section{Moderation Regression}

From the results of the regression test that the author conducted on the motivational variable as a moderating variable, it can be seen that the XM variable (motivation variable as a moderating variable) has a significant value of $0.735(\mathrm{Sig}=0.735>=0.05)$. This illustrates that the motivation variable as a moderating variable is significant. This also illustrates that the motivation variable as a moderating variable has an effect on the relationship between work discipline (X) and employee performance (Y).

The value for the motivation variable as a moderating variable is 0.340 , meanwhile with $=5 \%$ $\mathrm{df}(\mathrm{n}-2)=(68-2)$ is 1.996 . If $>$ then it is rejected and accepted, whereas if $<$ then it is accepted and rejected.

The motivation variable as a moderating variable, the value $(0.340)<(1.996)$ means that it is accepted and rejected. This indicates that there is an influence between work discipline () on employee performance $(\mathrm{Y})$ with the motivation variable as a moderating variable.

\section{The coefficient of determination}

That the coefficient of determination is the R square value of 0.673 . This means that $67.3 \%$ of employee performance variables are explained by the independent variables of work discipline, motivation, and XM. While the remaining $32.7 \%$ is explained by other causes outside the model.

Based on the results of the first regression test, the R Square value was 0.362 or $36.2 \%$. Meanwhile, from the results of the second regression test, the $\mathrm{R}$ square value was 0.673 or $67.3 \%$. So motivation as a moderating variable gives an increase in influence of 0.311 or $31.1 \%$.

\section{Discussion}

\section{The Effect of Work Discipline on Employee Performance.}

The results of the regression test conducted by the author on the Work Discipline variable () on Employee Performance (Y). It can be seen that the Employee Performance variable 
(Constant) has a significant value of $0,000(\mathrm{Sig}=0,000<=0.05)$ and also the Work Discipline variable () has a significant value of $0,000(\mathrm{Sig}=0,000<=0.05)$. This illustrates that the results of this study are significant. This also illustrates that there is a significant influence between the work discipline variable () on employee performance (Y).

The overall correlation value $(R)$ is 0.602 . If the value of $R$ is positive $(+)$ then the correlation is proportional, if $\mathrm{R}$ is negative, then the correlation is inversely proportional. Referring to the provisions of the guidelines for interpreting the Efficiency value of 0.60-0.799, the correlation is strong, so the value of 0.602 indicates that the correlation between Work Discipline () and Employee Performance (Y) has a strong relationship. [4]

Based on the results of the $t$ test, it can be seen that the value for the Work Discipline variable () is 6.125 , meanwhile with $=5 \% \mathrm{df}(\mathrm{n}-2)=(68-2)$ is 1.996 . If $>$ then it is rejected and accepted, whereas if $<$ then it is accepted and rejected. Work Discipline Variable () value $(6.125)>(1.996)$ means rejected and accepted. This indicates that there is a significant influence between Work Discipline () on Employee Performance (Y).

From the R Square value in the first regression equation of 0.362 , it can be said that the Work Discipline variable has an effect on the Employee Performance variable by $36.2 \%$.

The results of previous research conducted by Priyono et al (2015) also note that work discipline affects employee performance with a significance level of 0.020 .

\section{The Influence of Motivation as a Moderation Variable, the relationship between work discipline and employee performance}

From the results of the regression test that the author conducted on the motivational variable as a moderating variable, it can be seen that the XM variable (motivation variable as a moderating variable) has a significant value of $0.735(\mathrm{Sig}=0.735>=0.05)$. This illustrates that the motivation variable as a moderating variable is significant. This also illustrates that the motivation variable as a moderating variable has an effect on the relationship between work discipline (X) and employee performance (Y).

Based on the table 4.79 above, it can be seen that the value for the motivation variable as a moderating variable is 0.340 , meanwhile with $=5 \% \mathrm{df}(n-2)=(68-2)$ is 1.996 . If $>$ then it is rejected and accepted, whereas if $<$ then it is accepted and rejected.

The motivation variable as a moderating variable, the value $(0.340)<(1.996)$ means that it is accepted and rejected. This indicates that there is an influence between work discipline () on employee performance $(\mathrm{Y})$ with the motivation variable as a moderating variable.

Based on the results of the first regression test, the R Square value was 0.362 or $36.2 \%$. Meanwhile, from the results of the second regression test, the R square value was 0.673 or $67.3 \%$. So motivation as a moderating variable gives an increase in influence of 0.311 or $31.1 \%$.

\section{Conclusion}

Based on the results of the analysis and discussion, the following conclusions were obtained:

a. Work Discipline has a significant influence on Employee Performance (Y), as evidenced by the value for the Work Discipline variable () is greater than the value. This indicates a significant influence between Work Discipline () on Employee Performance (Y) at the Inspectorate Office of Musi Rawas Regency. So it can be said that the hypothesis is accepted. 
b. Motivation as a moderation variable has an effect on the relationship between Work Discipline () and Employee Performance (Y). Thus, motivation (as a moderation variable has an effect on the relationship between work discipline () and employee performance (Y) at the Inspectorate Office of Musi Rawas Regency, thus it can be concluded that the hypothesis is accepted. So, it can be said that the motivation variable (as a moderation variable affects the relationship between work discipline variables) ) on Employee Performance (Y).

\section{Suggestion}

Based on the conclusions that have been put forward, the researcher provides the following suggestions:

a. For the Inspectorate Office of Musi Rawas Regency:

1. Work discipline that has been running should be maintained and improved, especially employees at the Inspectorate Office of Musi Rawas Regency. In addition, the results of observations at the Inspectorate Office of Musi Rawas Regency also show that a good relationship between superiors and employees as well as fellow employees can affect the level of work discipline. Therefore, the harmonious atmosphere that has been created should be maintained and improved again at the Inspectorate Office of Musi Rawas Regency.

2. Motivation as a moderation variable has an influence on the relationship between work discipline and employee performance. So, giving motivation to employees is important so that giving motivation should be further improved at the Inspectorate Office of Musi Rawas Regency so that employee performance can increase even more.

b. The results of this study can be used as reference material for further research. Further research can develop this research using other methods in examining Work Discipline and Employee Performance with Motivation as a Moderation variable.

\section{References}

A. P. Mangkunegara, Manajemen Sumber Daya Manusia Perusahaan, Dua Belas. Bandung: PT Remaja Rosdakarya, 2015.

E. Sutrisno, Manajemen Sumber Daya Manusia, Pertama. Jakarta: Kencana Prenadamedia Group, 2015.

Wibowo, Manajemen Kinerja, Kelima. Jakarta: Rajawali Pres, 2016.

Sugiyono, Metode Penelitian Kuanitatif, Kualitatif dan R\&D, Cetakan ke. Bandung: Alfabeta, 2017.

M. Sumardjo, Manejemen Pengembangan Sumber Daya Manusia Konsep-Konsep Kunci, Pertama. Bandung: Alfabeta, 2018.

M. S. P. Hasibuan, Manajemen Sumber Daya Manusia, Dua Dua. Jakarta: PT Bumi Aksara, 2018.

S. P. Siagian, Manajemen Sumber Daya Manusia, Dua Lima. Jakarta: PT Bumi Aksara, 2016.

A. Prihantoro, Peningkatan Kinerja Sumber Daya Manusia Melalui Motivasi, Disiplin, Lingkungan Kerja, dan Komitmen, Pertama. Yogyakarta: Group CV Budi Utama, 2015.I. L. Sumbung and S. Falah, "PENGARUH MOTIVASI DAN DISIPLIN TERHADAP KINERJA PEGAWAI DENGAN PEMBERIAN INSENTIF SEBAGAI VARIABEL MODERASI 
(Studi Kasus di Sekretariat Daerah Kabupaten Jayawijaya),” J. Kaji. Ekon. Dan Keuang. Drh., vol. 2, no. 1, pp. 1-16, 2017.

L. Dotulong and S. Assagaf, "Pengaruh Disiplin, Motivasi Dan Semangat Kerja Terhadap Produktivitas Kerja Pegawai Dinas Pendapatan Daerah Kota Manado," J. Ris. Ekon.

Manajemen, Bisnis dan Akunt., vol. 3, no. 2, pp. 639-649, 2015.

Priyono, MarZuki, and Y. Soesatyo, "Influence Of Motivation And Discipline On The Performance Of Employees ( Studies On , CV Eastern Star Home In Surabaya ),” J. Glob. Econ. Manag. Bus. Res., vol. 5, no. 3, pp. 212-220, 2015, doi: 10.1109/MM.2011.42.

E. W. Winarni, Teori dan Praktik Penelitian Kuantitatif Kualitatif Pendidikan Tindakan Kelas (PTK) Research and Development (R\&D), Pertama. Jakarta: Bumi Aksara, 2018. 